\title{
TRAVELING CHAUCER: COMPARATIVE TRANSLATION AND COSMOPOLITAN HUMANISM
}

\author{
Candace Barrington \\ Department of English \\ Central Connecticut State University
}

\begin{abstract}
Aвstract. Through the comparative study of non-Anglophone translations of Geoffrey Chaucer's The Canterbury Tales, we can achieve the progressive goals of Emily Apter's "translational transnationalism" and Edward Said's "cosmopolitan humanism." Both translation and humanism were intrinsic to Chaucer's initial composition of the Tales, and in turn, both shaped Chaucer's later reception, often in ways that did a disservice to his reputation and his verse. In this essay, Candace Barrington argues that comparative translation provides a means whereby new modes of translation, like Apter's, can promote a different version of humanism, like Said's; she demonstrates this process in a brief philological study of Nazmi Ağll's Turkish translation of The Squire's Tale. While we can see the infusion of Turkish values and perspectives in the new text, we can also see that the Turkish reveals new insights into Chaucer's subtle and nuanced use of language.
\end{abstract}

Geoffrey Chaucer was not a humanist. Nor did he presage historical humanism, an extended period in intellectual history, beginning with the Italian trecento and ending with Euro-American modernism. Nevertheless, for over 400 years, his Canterbury Tales were appropriated and refashioned to meet the demands of ever-morphing humanist causes, a frequently uneasy fit. His bawdy comedy was reconfigured to fit paradigms of high seriousness; his multilayered tales were culled and shuffled in order to demonstrate essentialist certainties. Throughout, as humanism became marked less by the recovery of classical ideals and more by the global promotion of these ideals as universal and timeless, Chaucer and his tales were made into amenable traveling companions at home and abroad. Translations abetted this transformation from medieval poet to the English wellspring of "the best which has been thought and said in the world." ${ }^{1}$ Indeed, by simultaneously modernizing Chaucer's medieval vernacular and bowdlerizing any objectionable passages, translations were key to shoehorning The Canterbury Tales into successive humanist paradigms.

No wonder scholars have derided humanist readings and modern translations of Chaucer's Tales. ${ }^{2}$ But new perspectives on both humanism and translation suggest now is the moment to approach The Canterbury Tales through a new mode of

1. Matthew Arnold, "Culture and Anarchy" (1882), accessed July 9, 2014, http://www.library.utoronto. ca/utel/nonfiction_u/arnoldm_ca/ca_ch-1.html.

2. For two influential critiques of humanist-inflected readings of Chaucer and his verse, see Lee Patterson, Negotiating the Past: The Historical Understanding of Medieval Literature (Madison: University of Wisconsin Press, 1987), 3-74; and Stephanie Trigg, Congenial Souls: Reading Chaucer from Medieval to Postmodern (Minneapolis: University of Minnesota Press, 2002), 144-194. Recent reception studies of Chaucer's oeuvre have frequently despaired over the quality of translations into post-medieval English. See, for example, Steve Ellis, Chaucer at Large: The Poet in the Modern Imagination (Minneapolis: University of Minnesota Press, 2000), 98-120; Joseph A. Dane, Who Is Buried in Chaucer's Tomb? Studies in 
translation that opens a different version of humanism. With this potential opening in mind, Jonathan Hsy and I recently launched Global Chaucers, a multilingual, multinational effort to locate, catalog, and study non-Anglophone translations and appropriations of Chaucer's corpus. Methodologically, Global Chaucers relies on a principle I call comparative translation, the philological study of a single author's work across various translations. This paradigm activates translational transnationalism (as suggested in the work of Emily Apter) in order to realize cosmopolitan humanism (as suggested in the work of Edward Said). ${ }^{3}$ By bringing together new modes of translation and humanism, comparative translation allows one previously disparaged practice - translation - to rehabilitate the other - humanism.

By undertaking this recuperative task, Global Chaucers revitalizes Lee Patterson's not-too-distant call for a humanist study of Chaucer that "preserve[s] and understand[s] threatened categories of difference." ${ }^{4}$ For Patterson, the most significant category of difference is between the past and the present. For Global Chaucers, the significant category of difference is between minority languages and globally dominant English. Whereas Patterson seeks to preserve difference by maintaining the fiction that the past can exist as an "equal and independent" entity apart from the present's recreation of it, our project seeks to understand different linguistic communities by eradicating a fiction, in this case the fiction that minority cultures cannot be coequals to Anglophone English culture. ${ }^{5}$ With this fiction removed, Global Chaucers is set to participate in a revitalized humanism, transhistorical and cosmopolitan in its compass, and always emphasizing the search for polyphonic modes of understanding.

Global Chaucers contributes to cosmopolitan humanism by applying comparative translation methodologies to non-Anglophone translations of Chaucer's verse. Chaucer is an apt vehicle for testing the ways comparative translation enriches cosmopolitan humanism, beginning with precisely the characteristic that made Chaucer problematic for traditional humanism: his Middle English text does not

the Reception of Chaucer's Book (East Lansing: Michigan State University Press, 1998), 95-135; David Matthews, "Infantilizing the Father: Chaucer Translations and Moral Regulation," Studies in the Age of Chaucer 22 (2000): 93-113; and Janne Goldbeck, "The Absent Father: Translating Chaucer's Canterbury Tales," Rendezvous 32, no. 1 (1997): 87-93.

3. Emily Apter, The Translation Zone: A New Comparative Literature (Princeton, New Jersey: Princeton University Press, 2006); and Edward Said, Humanism and Democratic Criticism (New York: Columbia University Press, 2004).

4. Lee Patterson, Negotiating the Past: The Historical Understanding of Medieval Literature (Madison: University of Wisconsin Press, 1987), 72.

5. Ibid., 73 .

CANDACE BARRINGTON is Professor in the Department of English at Central Connecticut State University, 302-1 Willard Hall, New Britain, Connecticut 06050; e-mail <BarringtonC@ccsu.edu>. Her primary areas of scholarly interest include the intersection of legal and literary discourse in late medieval England, popular representations of Chaucer and his verse, and non-Anglophone translation of The Canterbury Tales. 
consciously present instrumental humanist values, so none need be accounted for. That distance from traditional humanism, however, does not discount Chaucer's complex relationship to humanism (as well as translation), a relationship I review in a necessarily brief survey of both Chaucer's early engagement as a translator of trecento humanism and the ways his work (often translated into a contemporaneous English) was appropriated to advance the humanist agenda from the late fifteenth century to the mid-twentieth century. After this review I pause to consider the theoretical implications of comparative translation for our understanding of both translation practice and humanistic study.

With those parameters established, I analyze examples from Nazmi Ağ1l's Turkish translation, Canterbury Hikâyeleri, to present the hermeneutic cycle that translations instigate and how they contribute to the evolving, always unfinished project of understanding The Canterbury Tales. ${ }^{6}$ Rather than examine Ağll's and any other translation for what they teach the receiving culture about Chaucer and medieval English mores, I listen closely to these translations for what they reveal about the receiving culture as well as about our inability to hear everything in Chaucer's Middle English text. Through championing comparative translation, this essay demonstrates how studying translations of this canonical text of Eurocentric humanism contributes to a more cosmopolitan humanism whereby the "'Other' ... is the source and resource for a better, more critical understanding of the 'Self.'"'7

\section{Chaucer, Humanism, and Translation}

No matter where one starts, it is difficult to disengage the study of Chaucer from either humanism or translation. For Geoffrey Chaucer himself, humanism and translation were ineluctably linked. He was among the first Englishmen to encounter Italian trecento humanism, and his verse bears traces of a historical moment marked by both a concern for recovering classical ideals uncontaminated by Christian scholasticism and an implicit commitment to well-regulated oratory servicing the state. ${ }^{8}$ Chaucer would have encountered the early humanist writings in Italy while an envoy for Edward III and then later for Richard II, as he accompanied noble entourages trusted with marriage, trade, and political negotiations at Italian courts in republican Florence (1373) and despotic Milan (1378).9 He was likely tapped for these tasks because he could communicate in several Mediterranean languages, a facility developed (we suppose) as a boy frequenting the London docks surrounding his father's wine import business and as a youth

6. Geoffrey Chaucer, Canterbury Hikâyeleri, trans. Nazmi Ağıl (Istanbul: Yapı Kredi Yayınları, 1994).

7. Akeel Bilgrami, "Foreword," in Said, Humanism and Democratic Criticism, xii.

8. Colin Burrow, "The Experience of Exclusion: Literature and Politics in the Reigns of Henry VII and Henry VIII," in The Cambridge History of Medieval English Literature, ed. David Wallace (Cambridge: Cambridge University Press, 1999), 801-806; and James Simpson, Reform and Cultural Revolution, 1350-1547, vol. 2 of The Oxford English Literary History (Oxford: Oxford University Press, 2002), 20.

9. Derek Pearsall, The Life of Chaucer: A Critical Biography (Oxford: Blackwell, 1992), 9-137. 
in the Countess of Ulster's and Prince Lionel's Francophone households. ${ }^{10}$ While in Italy, he read Dante, Petrarch, and Boccaccio, the great triumvirate of trecento literature; according to the conventional account of Chaucer's poetic career, he evolved from a Frenchified court poet into an English poet energized by the Italians' larger claims to membership in the literary canon. Though Chaucer's reaction to the Italian trecento was complex and has elicited multiple nuanced readings, for the purposes of this essay we can briefly state that, as a poet of his times, he translated what he read. ${ }^{11}$ From 1380 onward, the Italians permeate his writing: Troilus and Criseyde and The Knight's Tale transform Boccaccio; Troilus's lyrics refract Petrarch; The Clerk's Tale engages dueling versions of the Griselda tale by Petrarch and Boccaccio; and The House of Fame, The Monk's Tale, and the closing lines of Troilus and Criseyde evidence Chaucer's complex response to Dante. Though seldom credited with fully understanding trecento humanism when he translated it, he can be credited with interpreting, resisting, and transmitting trecento humanism, thereby using translation to prepare fertile ground for Tudor England's homegrown humanist learning.

In terms of Chaucer's reception, ties to translation and humanism are equally complex yet more troubled. He was quickly ensconced as a foundational figure for Anglophonic humanism - first as part of the Protestant, nationalist project of the sixteenth century, then as part of the imperial project in the nineteenth century - and his reception was frequently defined by a grand narrative of European (and most specifically English) superiority. Throughout, he and his verse were made to resemble the dominant values of the age. In the case of the early English humanists, his elevation is an oddity. Although they stigmatized medieval culture, Henrician intellectuals repeatedly excepted Chaucer and his verse, which, predating the Protestant reformation by over a century, were fashioned and preserved by early humanists as exemplars of a latent Protestant literary tradition written in a simple native style, anticipating later political and religious events that unshackled England from the burden of the medieval church. ${ }^{12}$ Chaucer's commitment to Englishing classical narratives, his condemnation of abuses perpetrated by the Roman Church, his sympathetic portrayal of the "Lollard" parson, and his fascination with the individual - all served to make Chaucer a poet who, according to Philip Sidney, could be forgiven his "great wants" because "he in that misty time could see so clearly." 13

10. Jonathan Hsy, Trading Tongues: Merchants, Multilingualism, and Medieval Literature (Columbus: The Ohio State University Press, 2013), 27-29.

11. David Wallace, Chaucerian Polity: Absolutist Lineages and Associational Forms in England and Italy (Palo Alto, California: Stanford University Press, 1997); Jennifer Summit, "Topography as Historiography: Petrarch, Chaucer, and the Making of Medieval Rome," Journal of Medieval and Renaissance Studies 30, no. 2 (2000): 211-246; and Simpson, Reform and Cultural Revolution, 64.

12. Simpson, Reform and Cultural Revolution, 7-33 and 45-46.

13. Christopher Baswell, "England's Antiquities: Middle English Literature and the Classical Past," in A Companion to Medieval English Literature and Culture, c. 1350 - c. 1500, ed. Peter Brown (Malden, 
By the time John Dryden identified the Canterbury pilgrims as "our fore-fathers and great-dames" in 1700, Chaucer was considered the only pre-Reformation English poet worthy of humanism's laurels. Dryden accorded Chaucer this ranking because the medieval poet had been the first to eschew other languages and embrace English as a poetic language. Although many of the Canterbury figures - the "Monks and Friars, and Canons, and Lady Abbesses, and Nuns" - had been driven from the English landscape, Dryden argued they merited continued attention because "their general characters are still remaining in mankind, ... for mankind is ever the same, and nothing lost out of nature, tho' everything is alter'd." ${ }^{\prime 14}$ For Dryden, Chaucer's pilgrims had come to represent all the men and women not only of England but also of humanity. Chaucer thus merited Dryden's modernizing translation.

In the nineteenth and twentieth centuries, a repeatedly updated and frequently translated Chaucer went global, traveling abroad first as part of the nineteenth-century imperial project to disseminate - in the guise of universal humanism - British values as a means to assert hegemony over unruly heathens, and later as part of America's institutionalizing of those values. In the Tales, readers could find a pattern of discordant voices being displaced by an aesthetic celebration of English order, a displacement especially congenial to those who would invent and teach a canon of English poetry that set Chaucer at its source. Students in British colonial schools encountered diluted excerpts, and adults carried anthologies and pocket volumes featuring Chaucerian selections, most notably tidbits from the Tales, the lyric "Flee from the Press" with its concise maxims, the faux-Chaucerian The Floure and the Leaf with its vision of female passivity, and The General Prologue's portrait collection peopled with eccentrically English characters serving as universal types. A reader would have learned from the introductory notes in the likes of Bell's British Library that these selections exemplified the world of English gentlepersons: a civilized society of manly men and demure women, always noble and brave, bearing the stiff upper lip and possessing a clear understanding of one's place in society - values England meant to inculcate in those it conquered. In the United States, Chaucer was included in small encyclopedias of literature that became institutionalized in the early twentieth century as the Great Books. Wedged between the first volumes of ancient texts associated with humanism and later volumes containing modern paragons of rationality and literary excellence, Chaucer sat Janus-like between the old and the new, exemplifying the English language's trustworthy stewardship of the grand tradition.

Chaucer's empire-building role constitutes an essential change of his status in the translatio studii, the medieval explanation of knowledge's transmission progressively westward from Mesopotamia, to Greece, to Rome, to Western Europe,

Massachusetts: Blackwell, 2007), 231-46; and Philip Sidney, "The Defense of Poesy," in Sir Philip Sidney: A Critical Edition of the Major Works, ed. Katherine Duncan-Jones (Oxford: Oxford University Press, 1989|, 212-250.

14. John Dryden, Fables: Ancient and Modern (London, 1721). 
and finally to England. Along with Shakespeare, the other culminating figure in this process's first stage, Chaucer went from being the recipient of the grand tradition to embodying it, traveling the globe as part of the British dissemination of Eurocentric culture. At first a minority and insular language in the fourteenth century, English had become a dominant global language by the end of the twentieth, and Chaucer had become an authoritative figure transmitting codified certainties to otherwise benighted cultures. This history makes Chaucer and his texts complicit in humanism's darker side that would impose one set of universal values on everyone or would so promote its own value that it denies the equivalence (or even viability) of other systems, even to the point of trying to erase or misrepresent those systems. Because this form of humanism was wedded to a vision of inspiring literature that conveyed an important message, translation was not a problem. The strength of that message could survive the trauma of being translated from one language to another. What mattered was transmitting the essential truth. Consequent to Chaucer's identification as an agent of universalizing humanism were significant sacrifices in Chaucerian texts. Those targeting Anglophone readers were transformed to appeal to the modern reader; frequently stripped of verse and rendered into prose, they eliminated much of the medieval text's bawdiness, its ambiguity, and its distinctly medieval flavor. Those targeting non-Anglophone readers were also bowdlerized, often reduced to a selection of well-told tales. Chaucer's ties to humanism's discredited project began to unravel after World War II when The Prioress's Tale's anti-Semitism seemed too closely affiliated with Western European culture's dangerous grand narratives of cultural superiority. ${ }^{15}$ Although both instrumental humanism and functional translation served to disseminate Chaucerian texts globally, neither served his reception well.

\section{Comparative TransLation}

Because translation and humanism (individually and collectively) have shaped Chaucer's reception in now disgraced projects, it would be easy to reject both as not helping our understanding of Chaucer's current global reception. Despite this regressive history, recent reconsiderations have seen both translation and humanism as more culturally bound than once allowed, thereby providing progressive models for understanding non-Anglophone translations of Chaucer. Because these models - in the form of translational transnationalism and cosmopolitan humanism - are defined more by their goals than by their methodologies, I address that gap with comparative translation.

In suggesting that translation studies can nourish humanism through comparative translation, I bring together the work of Edward Said and Emily Apter. In Humanism and Democratic Culture, Said argues for a form of humanism that rejects "a lazy or laissez-faire feel-good multiculturalism" and in its place supplies

a far more rigorous intellectual and rational approach that ... draws on a rather exact notion of what it means to read philologically in a worldly and integrative, as distinct from separating

15. Seth Lerer, "Major Works, Major Issues: The Canterbury Tales," in The Yale Companion to Chaucer, ed. Seth Lerer (New Haven, Connecticut: Yale University Press, 2006), 277. 
or partitioning, mode and, at the same time, to offer resistance to the great reductive and vulgarizing us-versus-them thought patterns of our time. ${ }^{16}$

He labels this form of humanism "cosmopolitan." Although Said carefully delineates the attitude cosmopolitan humanism would bring, he does not fully explain how it would work. That is, how do we ensure "the canonical humanities" would "always remain open to changing combinations of sense and signification" rather than be "finished and settled once and for all"? ${ }^{17}$ More importantly, how do we bring the necessary number of voices and perspectives into "this agonistic process" to avoid simply another example of the educated, English-speaking elite dominating the conversation? ${ }^{18}$

Similarly, Apter's work with translational transnationalism calls for a "critical praxis capable of adjusting literary [techniques] — interlinear translation, exegesis, gloss, close reading - to the exigencies of contemporary language politics." ${ }^{19}$ Apter reminds us that in both originating and receiving texts, the cultural and linguistic context shapes the logos of the text in ways outside either the original author's or the translator's control, but not outside their awareness. Because she dismantles the traditional hierarchy granting value to languages and cultures based on whether they are dominant or minority, she helps us imagine how translational transnationalism can contribute to Said's cosmopolitan humanism.

The mediating philological practice is comparative translation, the attentive comparison of multiple translations of a single originary text. It becomes a useful methodological tool for achieving the goals of translational transnationalism and cosmopolitan humanism because it corrects the essentializing tendencies of both functional translation and instrumental humanism. Blurring the roles of subject and object, comparative translation acknowledges both translation and humanism as dialogical, incomplete activities. Here, the cultural artifact and its message are not imposed on one culture by another, as happened with instrumental humanism; instead, they are received, via translation, by new cultures with varying degrees of familiarity and foreignness as a way to learn about the originating culture and its values.

Furthermore, comparative translation does not allow the exchange to stop at this point. The now-translated text is returned to its originating culture - via a philological, descriptive retranslation — transformed to reveal what the originating culture might otherwise not understand about the receiving culture or itself. In this exchange, the receiving culture has as much to give to the originating culture as it received. Comparative translation takes translation studies beyond even the cultural turn, which focused on how the receiving language and culture shape the

\footnotetext{
16. Said, Humanism and Democratic Criticism, 50.

17. Ibid., 25.

18. Ibid.

19. Apter, The Translation Zone, 5; and Emily Apter, "Untranslatables: A World System," New Literary History 39, no. 3 (2008): 583.
} 
translation, by treating the two texts as coequals. ${ }^{20}$ This rehabilitative force derives from the mediation of the translator's granting sustained philological attention to both sides of the exchange. By building on the translator's insight into the originary text, comparative translation makes us privy to one of the most intimate forms of close reading - for who knows a text better than a conscientious translator who labors to account for every word in the original? And by retranslating the translation back into (a form of) the originating language, we can listen to the receiving culture speak back, both describing itself and revealing hidden aspects of the originary text.

Comparative translation's praxis is threefold: First, it works to create a democratic community of translators, readers, scholars, and texts - a sort of linguistic civitas "off the power grid of dominant world languages that grapples with the ways languages and texts create meaning. ${ }^{21}$ Second, its philological practice seeks out nodal points of incommensurability: textual moments in both the originating and the receiving texts are marked by "what may be hidden or incomplete or masked or distorted." ${ }^{22}$ And third, it depends upon an intense curiosity about what happens outside any individual's native culture. This threefold praxis suggests that for practitioners of comparative translation, the most important word in Terence's maxim - "Homo sum: humani nil a me alienum puto" — is not homo or humani but alienum; that is, an initial, and perhaps long-term, alienation marks our relationship to other humans and human cultures. Because the phrase does not describe an essentially permanent state, it can be taken up as a guideline obligating us to engage everything as yet alien and fascinating in its alterity. Comparative translation requires that an individual (homo sum) be like Terence's busybody and take an intense interest in that alienum. ${ }^{23}$

A widely translated author like Chaucer is an ideal entry point for such an exploration. In comparative translation's linguistic civitas, each translation is examined not for its adherence to an ideal Chaucerian text, a standard impossible to measure much less attain, but for those nodal points of incommensurability, textual moments where the two cultures have difficulty understanding one another, where the translator must intervene and attempt some sort of mediation. Chaucer is chock-full of those points, and translations must somehow grapple with them. The linguistic civitas can be enlarged when we gather multiple translations, thereby creating a multicultural milieu that places values and texts in conversation with Chaucer and one another. Through comparative analysis of these translations, we can apprehend a cosmopolitan, textual humanism ready to absorb "the great

20. Verena Conley, "Living in Translation," Profession (2010): 20-21.

21. Said, Humanism and Democratic Criticism, 43-56; and Apter, "Untranslatables," 590.

22. Said, Humanism and Democratic Criticism, 59.

23. The Latin phrase first appears in Terence's comedy The Self Tormentor (Heauton Timorumenos), where the line provides cover for the speaker, Chremes, and his intrusion in the affair of others. For an in-depth discussion of the context for this line, see Joseph McAlhany, "Crumbs, Thieves, and Relics: Translation and Alien Humanism," in this issue. 
lessons of the past" and "still remain attuned to the emergent voices and currents of the present, many of them exilic, extraterritorial, and unhoused." 24

These translations are important for Anglophone readers to study because they provide a form of critical scrutiny otherwise unavailable to us. If we listen closely, the translations tell us about the receiving culture and allow us to understand the other culture as coequal to our own. Sometimes we can see the cultures are different but mutually intelligible to one another; at other times substitutions and gaps point to moments when aspects of the originary text cannot be tolerated in the receiving culture. For scholars who have invariably relied on Middle English texts, these translations reveal moments in Chaucer's language we might otherwise slide past. In other words, the translations are collected not as exotic curiosities, but as ways to take seriously Hans-Georg Gadamer's claim that translations disclose what is not fully apparent in the source language and provide access to embedded meanings otherwise unavailable in the originary text. ${ }^{25}$ On this foundation and within the boundaries of our project, Chaucer and the translator become coequals, and each translation of The Canterbury Tales becomes coequal to the Middle English version(s).

\section{Chaucer and Comparative Translation}

In using comparative translation to relocate Chaucer and The Canterbury Tales within cosmopolitan humanism, Global Chaucers and its collected translations take up where my earlier narrative left off, tracing the medieval poet's role in the translatio studii in which the corpus of Western learning traveled west, lodging hearthside in his Tales, before heading out to every corner of the globe and now existing in over fifty languages. Early on, I had to decide how to approach these translations, and I decided to rely upon what Paul Ricoeur calls "linguistic hospitality," a process built on renouncing the ideal of the perfect translation and accepting in its place the ideal of the competent and well-intentioned translator. In such a hospitable atmosphere, Global Chaucers can take advantage of the linguistic civitas built into the Global Chaucers project by the collaboration and conversation permeating the project. Initially, this permeation was a consequence of my limited facility. I approach this project not as a polylinguist, skilled in each of these receiving languages. Rather, I employ the retranslation exercise advocated by Ricoeur, an "exercise in doubling the work of the translator through minimal bilingualism: retranslate after the translator." ${ }^{26}$ In each case, I rely heavily on others to provide the retranslations, making this a collaborative project nonpareil. This design, born out of necessity, has yielded several unexpected advantages. ${ }^{27}$

24. Said, Humanism and Democratic Criticism, 11.

25. Hans-Georg Gadamer, Truth and Method, 2nd rev. ed., trans. Joel Weinsheimer and Donald G. Marshall (London and New York: Continuum, 2004), 387-389.

26. Paul Ricoeur, On Translation, trans. Eileen Brennan (London and New York: Routledge, 2006), 10.

27. For a similar approach, see Gideon Toury, Descriptive Translation Studies and Beyond (Philadelphia: John Benjamins, 1995), 221-240. 
My conversations with translators and readers of the translations create a sense of community and common purpose that has allowed the project to mushroom in a short period of time. To provide a thread of consistency across this community of diverse collaborators, I deploy a list of basic questions that cover all sorts of grounds, from the reasons for making the translations and selecting the base text to semantic, syntactical, and cultural decisions. These questions work to reveal and explore moments of incommensurability that allow me to revisit Chaucer's text from a fresh perspective. Currently, I am conducting e-mail interviews in English with translators working in seven languages - Hungarian, Estonian, Farsi, Brazilian Portuguese, Afrikaans, Turkish, and Polish — and I have begun interviewing readers of four translations - Arabic, Chinese, Turkish, and Korean; I thus have a window onto an initial set of ten translations. ${ }^{28}$

As the project amasses translators' and readers' responses, we will be able to address two central sets of questions: the first set explores what the translations reveal to us about the receiving culture; the second set (more important for Chaucerians and other medievalists) asks what the translations can teach us about Chaucer's originary text. In this atmosphere of linguistic hospitality, careful study of each translation as a coequal to the original respects and maintains the ways languages and cultures differ from one another, allowing us to be concerned less about what judgments and evaluations we can make about them and more about what they can teach us about the receiving culture, about Chaucer's Middle English text, and about ourselves as native Anglophone readers of Chaucer. Some of these larger goals can be glimpsed in my preliminary studies with these translations.

Here, my focus is the first 205 lines of a Turkish translation of The Squire's Tale, chosen for three reasons. First, it is thus far the only translation for which I have conducted interviews with both the translator and a reader. The translator is Nazmi Ağıl, whom I met and interviewed in Istanbul in April 2013. The reader is Leyla Zidani-Eroglu, a linguist, department colleague, and native speaker of Turkish. Her comments were based on a comparison of Chaucer's English text and Ağll's Turkish translation. Previous to this encounter, she had never read any of Chaucer's Tales. As you will see, her expertise as a linguist leaves a distinctive mark on my approach. Second, A ğ1l's 1994 complete translation of The Canterbury Tales is not a word-for-word crib designed to facilitate a Turkish reader studying the Middle English text. Instead, his translation attempts to capture the Chaucerian text without betraying either it or his Turkish audience. His accessible text evokes the antiquity of the middle ages not by reaching back to Turkey's medieval past but by tapping into the idioms and images associated with the more recent mid-twentieth-century past, a time when a sizeable portion of Turkey's population remembered the years prior to Atatürk's secularizing policies. As far as Ağ1l is concerned, the days when sultans and imams dominated Turkey's

28. For more information on this project, see www.globalchaucer.wordpress.com. The next step further broadens the collaboration. By uploading the translations in formats that allow for crowdsourcing, we will bring in readers who can develop conversations about the ways the translations create meaning. 
cultural landscape are distant enough to evoke a long-ago past for the readers he envisions. Because A $\breve{g} 1$ l's translation does not attempt what some would call a "faithful" rendition of the original, it might seem more suited as a way to teach us about contemporary Turkish culture than as a way to learn about Chaucer's originary text. As I hope to demonstrate, this unlikely candidate stands up to the challenge and supports my two claims: that the translation can teach us about its receiving culture and that it can open us to new understandings of Chaucer's Middle English text.

Third, I've chosen The Squire's Tale, or Silahtar'in Hikâyesi, because it provides a rich field of deictic moments - those moments of incommensurability when the text's semantics are defined, limited, and reconfigured by its context. These deictic moments are particularly apparent because Chaucer and Ağıl each write for an audience with a different relationship to the central characters, events, and locations in the tale, a romance set in the court of Cambyuskan (or Genghis Khan). ${ }^{29}$ The tale's events center on the court's celebration of Cambyuskan's birthday and the arrival of an imposing knight in service to the "kyng of Arabe and of Inde" (CT, 5.110). Riding a magical, mechanical horse, he delivers three more magical gifts to the great khan and his children: a ring (which allows the wearer to understand the language of birds), a mirror (which allows its bearer to know the thoughts of others), and a sword (which can both kill and heal). The unfinished tale stops after Cambyuskan's daughter, Canacee, has used the ring to hear the lament of a forlorn falcon.

For Chaucer, his Squire, and their audiences, Cambyuskan and his court are in far-off "Sarray, in the land of Tartarye" $(C T, 5.9)$. For Ağll, his Silahtar, and their audiences, the perspective is different: Cambinskhan is the grandsire of the Ottoman Empire; he fought battles just beyond modern Turkey's borders, and Sarray is nearby. ${ }^{30}$ Conversely, when a modern Turk thinks about medieval England, she does not imagine the Plantagenets' backwater kingdom on the far western edge of Europe. She imagines the predecessor to another great empire. Therefore, the deictic moments of place and time provide for my query two particularly intriguing entry points: first, the Squire's "here" of the English domestic countryside between Southwerk and Canterbury becomes for modern Turks the powerful British empire that the Ottomans failed to stave off and that Atatürk's reforms sought to emulate; second, the Squire's "now" in the emerging literary culture of late fourteenth-century England becomes for Turks the setting for a story that celebrates the birth of the Turks' political and cultural dominance

29. In the subsequent discussion of Chaucer's Middle English text and Ağıl's translation, specific references will be cited in the text; The Canterbury Tales is abbreviated as CT (and referenced by line number) and Canterbury Hikâyeleri as $\mathrm{CH}$ (and referenced by page number). The edition of The Canterbury Tales cited in this discussion is in Larry Benson, ed., Riverside Chancer, 3rd ed. (Boston: Houghton Mifflin, 1987).

30. When referring to Chaucer's Middle English tale-teller, his tale, and his protagonist, I use "Squire," "Squire's Tale," and "Cambyuskan." When referring to Ağll's Turkish translation, I use "Silahtar," "Silahtar'in Hikâyesi," and "Cambinskhan." 
for half a millennium. In addition to noting the ways the Turkish perspective allows for a different understanding of Cambyuskan and his court, I'm especially interested in the deixis of place and the ways inherent features of English and of Turkish create a sense of distance and proximity.

In Ağll's General Prologue portrait of the Squire (Silahtar) the pilgrim's Turkification is most noticeable in explicitly Turkish word choices. Here, the Silahtar sings Turkish folk songs (Türküler) and wears clothing decorated in a Turkish fashion (takmış takıştırmıştı) $(\mathrm{CH}, 35)$. More understated is the shifted emphasis in the portrait. The Turkish Silahtar embodies the courtly values we find in the Middle English original, but he does so in a particularly Turkish way, emphasizing his obedience to his father rather than his courtly performances. In addition to these semantic and cultural shifts, the translation also depends upon deictic moments that exploit the fact that Turkey and England occupied two ends of the medieval map. The Turkish suffixes appended to the sites of the Silahtar's expeditions into France emphasize a greater distance than the Middle English preposition "in"; the Turkish suffixes lend a sense of motion toward some place, thereby implying the long journey that an expedition from Turkey to France would entail. So Ağll's Silahtar is a fighter, lover, and courtly performer, but he is primarily a loyal son with noticeable Turkish inflections.

When we turn to the tale itself, we find various ways A $\breve{g}_{1}$ gives his translation a certain immediacy. In addition to truly relating a Türküler, for his tale is certainly a tale about the Turkish past, Ağıl's Silahtar uses several strategies: he creates a correspondence between his audience and the audience in Cambinskhan's court; he transforms indirect discourse into direct quotation; he replaces Chaucer's impersonal "a man" with a second-person pronoun; he uses idiomatic expressions; and he ascribes behavior directly to characters when Chaucer makes more general statements. He also, once again, takes advantage of the tale's geographic deixis. The most obvious case occurs when Chaucer's "in that lond" $(C T, 5.69)$ refers in the Turkish to Cambinskhan's land, a change made so that readers are not confused when he translates Chaucer's "in this land" $(C T, 5.71)$ as bizim ülkede $(\mathrm{CH}, 467)$, or "in our land." And as we saw in the portrait, the complex set of suffixes indicating location in Turkish creates precise relationships between the reader and the place names that open the tale. A $\breve{g} 1$ 's Turkish translation opens with Tataristan'da $(C H, 465)$ whose locative case suffix, -da, indicates a state of rest. ${ }^{31}$ The tale's second word, Sarray'da $(\mathrm{CH}, 465)$, also includes the locative case suffix, $-d a$, and the comitative suffix in Rusya'yla $(\mathrm{CH}, 465)$ continues that sense of the events happening nearby. That sense is further underlined by bu savasssta $(\mathrm{CH}, 465)$, a phrase that does not have a close equivalent in the Middle English text and that implies a certain shared knowledge about the battle between the Tatars and the Russians.

In keeping with its national interests, the Turkish presentation of Cambyuskan doubles down on the English Squire's over-the-top assessment of the great

31. Jaklin Kornfilt, Turkish, 2nd ed. (London: Routledge, 2010), 242. 
khan. Beyond being "in his tyme of so greet renoun" $(C T, 5.13)$, the Turkish Cambinskhan is of such perfection that no one comparable could be found across the seven climates and four corners of the world. And whereas the Squire's ambiguous "fair" could describe Cambyuskan's appearance or his probity, the Silahtar leans entirely towards the khan's moral qualities and not his looks. ${ }^{32}$ When the Middle English Squire feels he must remind the reader that he's been telling his reader about Cambyuskan, the Turkish Silahtar fills the line by identifying him as hikâyemizin kahramanı $(C H, 467)$, or our story's hero. When the Knight presents the mirror and ring to Canacee $(C T, 5.143-145)$, the Turkish translation includes a short phrase that indicates the Knight's efforts to ensure that his master is not seen as superior to Cambinskhan: çoban armağanıdır sultanımdan (CH, 469). This phrase literally means that "this is a shepherd's gift from his sultan," and it is used to suggest the lowliness of the gifts in comparison to the height of the Cambinskhan, his offspring, and his court.

Another telling deixis is the two different relationships that the Squire and the Silahtar have to the English language. In keeping with what we have learned about the Middle English Squire in his General Prologue portrait, when he apologizes for his rhetorical failures, his wording points to the limitations of "Englissh." It is an insufficient language: it does not provide a speaker with the tropes necessary to describe every part of Canacee's beauty; he must, as he demurs, speak within the limitations imposed by English. His rhetorical abilities are not great enough to overcome the limitations inherent in English. In the Turkish translation, it does not matter whether English is sufficient to describe Canacee's beauty. What makes more sense is the speaker's knowledge of English, and thus the translation emphasizes the narrating Silahtar's severe lack of English knowledge. It is not an insufficient language but his insufficient knowledge of English that impairs him. He emphasizes his distance from English eloquence by departing from a somewhat close translation of the Middle English and closing this passage with two lines of Turkish folk idioms nearly untranslatable into English.

More subtle is the way the Turkish shapes the tale through demonstrative adjectives and pronouns inherently different from the ones in Middle English. Turkish has three levels of demonstrative adjectives and declinable demonstrative pronouns: bu, şu, $o^{33}$ The first two correspond with English's "this/these" and "that/those," indicating proximity to or distance from the speaker. Turkish adds a third, o, which roughly translates as "yonder." 34 In the first 205 lines of Silahtar'in Hikâyesi, bu appears twenty-seven times. In fifteen of those occurrences, it points to a character or object in the story, thereby reflecting Chaucer's use of demonstrative adjectives in the corresponding passage. Nearly twice as many times as the Middle English uses "this" or "these," however, the Turkish text

32. Middle English Dictionary (online edition), s.v. "fair," adj., accessed July 9, 2014, http://quod.lib.umich.edu/m/med/.

33. Kornfilt, Turkish, 311-313.

34. Ibid., 106. 
uses bu, appearing as part of idiomatic phrases emphasizing that these elements belong "here" or that these events took place "here," further underlining the sense established in the opening lines that the Turkish teller and the setting of his tale are coexistent. Silahtar'in Hikâyesi's Turkish uses the more distant demonstrative pronoun - $O$ - to indicate hypotheticals or abstractions like Canacee's beauty $(\mathrm{CH}, 466), \mathrm{Cambinskhan's} \mathrm{height}(\mathrm{CH}, 467)$, the Knight's rhetorical style and skill $(\mathrm{CH}, 468)$, the faraway lands to which the brass horse can take its rider $(\mathrm{CH}, 468)$, the enemies that could be spied via the magic mirror $(\mathrm{CH}, 469)$, the language of the birds $(\mathrm{CH}, 469)$, the wound that could result from the magical sword $(\mathrm{CH}, 469)$, the horse's excellence $(C H, 470)$, and the strange events that have prompted the court's speculations. The mid-distant şu appears least often. As a demonstrative adjective, it appears only four times, and each time it introduces the next element in a process and does not deal with distance. Everything else is referenced or modified with bu, or "this/these," creating a sense of pointing to this place, these characters, these events. So in this passage, the main distinction is between bu and o - this close by and that yonder.

The Turkish demonstratives encourage us to revisit and rethink Chaucer's peculiar use of demonstratives. In many ways, the Turkish translation recognizes and emphasizes an easily overlooked distinction in Chaucer's use of demonstrative adjectives in the first 203 lines of The Squire's Tale. This Middle English passage contains only twenty-three demonstrative adjectives, and all but one the previously mentioned "that lond" - are "this" or "thise," suggesting an effort to create a sense of proximate closeness. That interpretation, paradoxically, is not the case. But for two exceptions (the phrase "in this world" [CT, 5.62], plus the contrasting phrases "that lond" and "this lond" [CT, 5.69 and 5.71]), the demonstrative adjectives modify either Cambyuskan (or a noun substitute) or the Knight and the three gifts he delivered. In this passage, the Middle English "this" has the effect of indicating the strange and the unusual, progressing from Cambyuskan, to the Knight, and then to his three gifts. Used this way, the demonstrative adjective "this" is more like the nonstandard "this here" in modern English, used to connote a certain alienation from something supposedly nearby. In this locution, the apparent proximity that "this" and "here" would seem to intensify is undermined and lessened by repetition. "This" is "here" but not from here or at least not someone or something I lay claim to. Although Chaucer does not use the "this here" locution, he invariably limits demonstrative adjectives so that his "this" feels very much like "this here": "this Tartre Cambyuskan" $(C T, 5.28)$, "[t]his strange knight" $(C T, 5.89)$, "[t]his steede" $(C T, 5.115)$, "[t]his mirour" $(C T, 5.132)$, "[t]his naked swerd" (CT, 5.156). All these demonstrative adjectives support the immediacy of the Squire's performance, while simultaneously and paradoxically exposing its distant setting.

Because Turkish has finely drawn and unavoidable deixis of place, A $\breve{g}_{1} l^{\prime} s$ Silahtar'in Hikâyesi prompts us to look at corresponding points in Chaucer's text and see it anew. These moments should not surprise us. We are working with a tale that already explores the compression of time and space via a magical brass horse whose mechanics instill great wonder in Cambyuskan's court. By reexamining 
it through the lens of A $\breve{g}_{1} l$ 's Turkish translation, we can see more clearly one of Chaucer's techniques for effecting and exposing that compression.

As this philological reading of A $\breve{g}_{1} 1$ 's translation indicates (but certainly does not exhaust), translations provide a new heuristic, adopting Chaucer's voice in a new tongue in order to explain what we might overlook. This process will be intensified once I complete more interviews and can compare A $\breve{g}_{1} 1$ 's translations to others. By returning The Canterbury Tales to a multicultural, polylingual milieu reminiscent of the one in which the Tales originated, comparative translation (whether with one translation or many) reinforces the Tales' inherent instability and ensures that Chaucer's text remains living, unfinished, and provoked out of resolution and complacency.

Comparative translation also reminds Anglo-American readers they live in a globalized culture, where Western traditions sit among a large variety of cultural and literary choices. It provides new perspectives on such cultural bugaboos as empire, capitalism, and Christianity - phenomena once considered the bedrock of humanism. Perhaps we could go so far as to say that Global Chaucers' comparative studies reinstate older paradigms of translatio studii. Because these translations are completed by native speakers of the receiving language rather than given by native-English-speaking translators to the receiving culture, they are less about imposing the English tradition upon another culture and more about taking from the English tradition. In this way, Global Chaucers and comparative translation model how cosmopolitan humanism can amalgamate, accommodate, and interrelate apparently incompatible traditions, each becoming "an unsettling adventure in difference." ${ }^{35}$

35. Said, Humanism and Democratic Criticism, 55.

MULTIPLE COMMUNITIES of translators, readers, and scholars made this study possible. Nazmi Ağıl and Leyla Zidani-Eroglu allowed me to interview them regarding the Turkish translation, and Zuleyha Cetiner-Oktem initiated the project when she introduced me to Nazmi. Mohammed Albakry, Krista Brune, Robin Ellis, Chris Higgins, Kaarin Johnston, Kjerstin Moody, Justine Pas, and Kathryn Vomero Santos helped me shape Global Chaucers' theoretical underpinnings while we studied together at the National Endowment for the Humanities Summer Institute for College Teachers, "The Centrality of Translation to the Humanities: New Interdisciplinary Scholarship," held at the University of Illinois at Champaign-Urbana (July 2013). Anya Adair, Ardis Butterfield, Ian Cornelius, Gina Hurley, and Annie Killian shared generous feedback through the Yale Medieval Colloquium and the 2014 Medieval Academy. And, once again, Mike Shea provided indispensable ground support. 